\title{
An Integrated Method for the Selection of Optimum Locations for Landfilling Utilizing GIS: A Case Study of the State of Kuwait
}

\author{
Meshal Mohammad Abdullah",2*, Sabah Al-Jenaid³, Waleed Khalil Zubari' ${ }^{4}$, Jasem Al-Ali ${ }^{5}$ \\ ${ }^{1}$ Department of Ecosystem Science and Management, Texas A\&M University, College Station, TX, USA \\ ${ }^{2}$ Natural Environmental Systems and Technology (NEST) Research Group, EcoLife Science Research and Consultation, \\ Hawally, Kuwait \\ ${ }^{3}$ Geoinformatics Department, College of Graduate Studies, Arabian Gulf University, Manama, Bahrain \\ ${ }^{4}$ Water Resources Management Program, College of Graduate Studies, Arabian Gulf University, Manama, Bahrain \\ ${ }^{5}$ Geography Department, College of Social Science, Kuwait University, Shuwaikh, Kuwait \\ Email: *mmabdullah@aggienetwork.com
}

How to cite this paper: Abdullah, M.M., Al-Jenaid, S., Zubari, W.K. and Al-Ali, J. (2019) An Integrated Method for the Selection of Optimum Locations for Landfilling Utilizing GIS: A Case Study of the State of Kuwait. Journal of Environmental Protection, 10, 260-275.

https://doi.org/10.4236/jep.2019.102015

Received: March 24, 2018

Accepted: February 12, 2019

Published: February 15, 2019

Copyright $\odot 2019$ by author(s) and Scientific Research Publishing Inc. This work is licensed under the Creative Commons Attribution International License (CC BY 4.0).

http://creativecommons.org/licenses/by/4.0/

\begin{abstract}
With the rise of urbanization, change in lifestyles, and food habits, the amount of Municipal Solid Waste (MSW) has been rapidly increasing with the composition constantly changing. Landfilling is the common approach for waste management in Kuwait, and around 90\% of municipal wastes are disposed in landfill sites. Therefore, this study focused on the integration of different methods for the process of allocating optimum sites for MSW landfills, in four main stages. The first stage focused on utilizing the gap analysis method for the identification of effective criteria for landfill site selection, by comparing the criteria in Kuwait with the World Bank guidelines, US EPA, and Australia EPA, to suggest the best criteria for landfill site selection. These criteria were applied in the second and third stages to determine suitable locations for landfill sites using the Geographical Information System (GIS). In the last stage, the suitable areas were evaluated by studying the socioeconomic aspects such as distance to waste generation center, the proximity of existing roads, and lifespan to select optimum locations for landfilling. The results indicated that only one site with a total area of $12 \mathrm{~km}^{2}$ was considered optimum for MSW landfill sites in Kuwait. Therefore, moderate suitability areas were indicated to support and provide decision makers with more options. The moderately suitable sites are also suitable for landfilling, but they need to be designed carefully in order to avoid negative impacts on the environment and human health. Therefore, we conclude that there is an urgent need to apply the integrated waste management system in Kuwait, as well as to develop a long-term strategic plan.
\end{abstract}




\section{Keywords}

Municipal Solid Waste, ModelBuilder, Gape Analysis, Spatial Analysis, Waste Management

\section{Introduction}

Population growth and changes in socio-economic structures increase the per capita consumption leading to more waste production, which has a detrimental impact on the environment [1] [2]. Municipal Solid Waste Management (MSWM) is considered one of the most crucial environmental challenges that developing countries face today [3] [4], as landfills are the common practices in most urban areas in developing countries because of their cost effectiveness [5]. Landfill site selection is also a critical issue in the urban planning process due to its enormous impacts on the economy [6], ecology, health, and environment [7] [8] [9].

Therefore, it is necessary to consider sanitary landfills which include an engineered facility for MSW, which is designed and operated to minimize public health and environmental impacts [10]. Sanitary landfills should be intended to protect humans and the environment from emitted gasses and fluids by using impervious liners, gas collection vents, and leachate collection pipes [11] [12]. Many landfills are designed for a lifespan of 20 or 30 years and still require post closure monitoring for up to 30 years to ensure that their environmental effects are controlled [13] [14]. Due to the negative impacts of landfilling on the environment and human health, selecting new proper landfill sites requires spatial process as well as identifying effective criteria [15] [16]. The criteria associated with landfill sitting can be grouped into three main categories, namely, engineering and infrastructure, environmental and socio-cultural, and economical [17] [18]. These criteria prohibit a landfill from being placed within a particular area. The selected criteria should be met by all acceptable landfill locations [19].

Geographic Information Systems (GIS) is one of the most common tools used in selecting landfill sites. GIS can manage and analyze varied amounts of data associated with the process of setting up solid waste landfills, as well as its flexibility, numerical efficiency in calculations involving combinations and statistical exploration of spatial variables [20]. Previous studies also illustrate that the integration of GIS and multi-criteria analysis is a powerful method for the selection of landfill sites [2] [21]. Moreover, GIS plays a significant role in providing a cost effective and efficient analysis of landfill site attributes; however, it can be limited to the lack of available data [17].

In Kuwait, the amount of municipal solid waste has been rapidly increasing and its composition has been changing due to the growth in population, rise of urbanization, and change in lifestyles and food habits. 90\% of the MSW is disposed in landfills and $10 \%$ is recycled [22] [23] [24]. Therefore, this paper 
presents an integrated approach for the selection of suitable locations for landfilling. The major objective is to develop a methodology for the selection of optimum landfill sites by integrating the ecological, social, and economical aspects using the Geographical Information System (GIS) and gap analysis technique. Specific objectives include: 1) developing a proper list of guidelines for the selection of landfill sites in Kuwait using the cap analysis approach, and 2) integrating environmental and socioeconomic criteria to select optimum locations for landfilling in Kuwait by utilizing GIS.

\section{Methods and Materials}

\subsection{Study Area}

The State of Kuwait is located in the northwestern corner of the Arabian Gulf. It encompasses an area of approximately 17,818 square kilometers extending between latitudes $28^{\circ} 30^{\prime} \mathrm{N}$ and $30^{\circ} 05^{\prime} \mathrm{N}$, and longitudes $46^{\circ} 33^{\prime} \mathrm{E}$ and $48^{\circ} 30^{\prime} \mathrm{E}$ ( $\mathrm{Al}$ Baz and Al Sarawi, 2000). Kuwait has a desert climate, hot and dry with occasional rain, mostly in the spring. Rainfall varies from 75 to $150 \mathrm{~mm}$ per year across the country. The summer seasons are relatively hot and are often accompanied by dust storms where the average daily temperatures in summer range from $42^{\circ} \mathrm{C}$ to $46^{\circ} \mathrm{C}$. The prevailing wind is in the northwest direction, and humidity increases during late summer with thunderstorms. However, the weather gets colder in late November, dropping temperatures to as low as $3^{\circ} \mathrm{C}$ at night; daytime temperature is in the upper $20^{\circ} \mathrm{C}$ range (Ministry of Planning, 2007).

\subsection{Methodology}

This study incorporates four stages for the selection of new MSW landfill sites in Kuwait (Figure 1). These stages include 1) the identification of sufficient criteria for site selection using gap analysis method, 2) determining unacceptable areas, 3) weighting the acceptable areas, and 4) studying the socioeconomic factors to evaluate the suitability of the selected areas in order to determine optimum locations for landfilling. The second and third stages were accomplished using spatial analysis and ModelBuilder in ArcGIS to produce suitability maps highlighting "suitable" geographic areas derived from weighted and combined map layers based on the established criteria in stage one.

\subsubsection{Identification of Suitable Criteria for Landfill Site Selection}

In this stage, Kuwait's regulation for landfill site selection, which was established by the Kuwait Environment Public Authority (EPA) was compared to the World Bank, Australia EPA, and US EPA guidelines using Gap Analysis. This stage was conducted in order to evaluate the current criteria in Kuwait by filling out any gaps. The World Bank guidelines have been developed as international requirements, which are applicable to any region. Thus, Kuwait and other selected countries' regulations are compared together based on the World Bank guidelines. Then, the gaps were analyzed to determine the ones that fit with the nature of Kuwait (Table 1). 


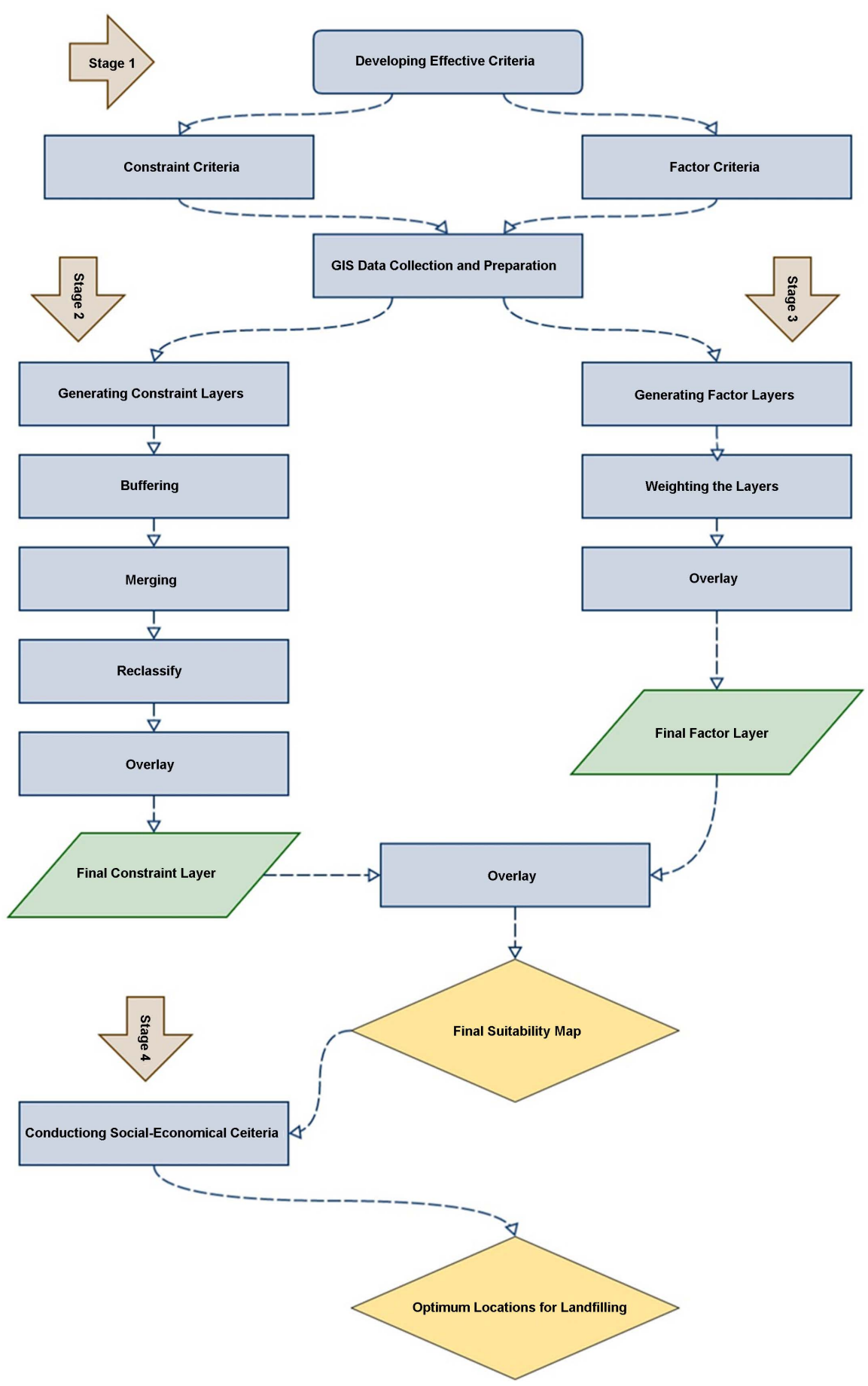

Figure 1. Study methodology.

\subsubsection{GIS Data Collection and Preparation}

Data availability is one of the most important steps when using GIS. Based on the established criteria in stage one, 30 layers (Table 2) have been collected from different governmental institutions including the Kuwait Institute for Scientific Research (KISR), Public Authority of Agriculture and Fish Resources (PAAF), Kuwait University (KU), and Kuwait National Focal Point (KNFP), with a scale of 1:250,000. However, the lack of availability of some data leads to the omission 
Table 1. Selected criteria for the selection of MSW landfill sites in Kuwait.

\begin{tabular}{cl}
\hline Criteria & \multicolumn{1}{c}{ Description } \\
\hline Hydrology & $\begin{array}{l}\text { Groundwater fields, wells and aquifers as well as water catchment } \\
\text { areas }\end{array}$ \\
Topography & $\begin{array}{l}\text { Slops, wetland area, rainfall areas, water catchment, wades and } \\
\text { moving sands }\end{array}$ \\
Protected areas & Current and proposed protected areas \\
Agriculture & Sites of archaeological importance \\
Land use & $\begin{array}{l}\text { Land use (urban, industries, roads, major lines, airport, military } \\
\text { areas, national parks, industrial, intensive animals farms, etc) }\end{array}$ \\
Soil & $\begin{array}{l}\text { Soil characteristics, soil permeability, and soil suitability for } \\
\text { irrigated agriculture }\end{array}$ \\
Geology & Rock penetration \\
Urban & Proximity to urban settlements \\
Hydrology & Proximity to groundwater fields, wells, depth \\
Agriculture and protected areas & Proximity to agriculture fields and protected areas
\end{tabular}

of their related cantons from the study, such as seismic zones, fault lines, archeological and historical areas, and vegetation types and communities. Furthermore, some of the available data have been collected in an analog format. They were first digitized into vector format by using on-screen digitizing and then introduced to the GIS system. All data were stored in the same coordinate system in order to display them together, and were all transferred to Universal Transverse Mercator (UTM) projection (WGS 1984, Zone 38N).

The digital elevation model (DEM) was built up by using 3D analysis tools. Contour lines and spot heights maps were used in building DEM map. The slope layer was derived from the DEM by using the surface function in the spatial analysis tools. However, depth to groundwater layer was created from the water level contour lines of Kuwait Group in the GIS software using the spatial analyses tools. Then, the differences between the groundwater levels and DEM were extracted using raster calculator in the spatial analyses tools to create the depth of groundwater layer.

\subsubsection{Determining Unacceptable Areas}

The present investigation was completed using ModelBuilder in GIS. This stage includes the logical combination of binary maps using constraint layers, which were used to distinguish between lands that are suitable for landfill siting and those lands that are restricted in order to determine the unacceptable areas for landfill site selection. Constraint layers were classified into six groups, where each group contains several layers (Table 3 ). These groups include groundwater, topographical aspects, soil, current and proposed land use areas, ecological aspects, and major infrastructure lines. Around 27 layers were applied in establishing the constraint maps following several geoprocessing in the GIS environment. Buffer distance was given to each constraint factor (Table 3). All 
Table 2. Collected GIS layers.

\begin{tabular}{|c|c|}
\hline Component & Layers \\
\hline \multirow{3}{*}{$\begin{array}{l}\text { Hydrology and } \\
\text { Geology }\end{array}$} & Groundwater level for Kuwait group \\
\hline & Water wells \\
\hline & Kuwait geological map \\
\hline \multirow{7}{*}{$\begin{array}{l}\text { Topography and } \\
\text { climate }\end{array}$} & Moving sand \\
\hline & Elevation contour lines \\
\hline & Spot elevation \\
\hline & Basin \\
\hline & Wetland area \\
\hline & Wadies \\
\hline & Sabkha \\
\hline \multirow{3}{*}{ Soil } & Soil map \\
\hline & Suitable soil map for irrigated agriculture \\
\hline & Limitation map for sanitary landfill sites based on the soil survey project. \\
\hline \multirow{10}{*}{$\begin{array}{c}\text { Build up and } \\
\text { developed areas }\end{array}$} & Military area \\
\hline & Current urban areas \\
\hline & Proposed urban area \\
\hline & Industrial location \\
\hline & Power lines \\
\hline & Power water station \\
\hline & Oil fields \\
\hline & Power station \\
\hline & Current airport \\
\hline & Proposed airports \\
\hline \multirow{5}{*}{ Ecology } & Current protected areas \\
\hline & Proposed protected areas \\
\hline & Agriculture areas \\
\hline & Birds communities \\
\hline & Intensive animal farms \\
\hline \multirow{4}{*}{$\begin{array}{l}\text { Major lines for } \\
\text { infrastructure }\end{array}$} & Current road networks \\
\hline & Proposed road network \\
\hline & Oil and gas pipelines \\
\hline & Power lines \\
\hline
\end{tabular}

developed layers were converted from vector format to raster format. The raster layers were reclassified into 0 and 1 in order to identify restricted and suitable areas for landfill site selection. This procedure created a constraint layer for each layer containing only two classes represented by 1 (for suitable land) and 0 (for 
Table 3. Constraint criteria and buffer distance.

\begin{tabular}{|c|c|c|}
\hline Component & Layers & Buffer \\
\hline Hydrology & Water wells & $2 \mathrm{~km}$ \\
\hline \multirow{6}{*}{ Topography and climate } & Moving sand & $500 \mathrm{~m}$ \\
\hline & Slops & $<2 \%$ \\
\hline & Basin & $300 \mathrm{~m}$ \\
\hline & Wetland area & $500 \mathrm{~m}$ \\
\hline & Wadies & $300 \mathrm{~m}$ \\
\hline & Sabkha & $500 \mathrm{~m}$ \\
\hline \multirow{7}{*}{$\begin{array}{l}\text { Build up and developed } \\
\text { areas }\end{array}$} & Military area & $1 \mathrm{~km}$ \\
\hline & Current and proposed urban area & $5 \mathrm{~km}$ \\
\hline & Industrial location & $500 \mathrm{~m}$ \\
\hline & Power water station & $500 \mathrm{~m}$ \\
\hline & Oil fields & $5 \mathrm{~km}$ \\
\hline & Power station & $500 \mathrm{~m}$ \\
\hline & Current and proposed airports & $3 \mathrm{~km}$ \\
\hline \multirow{4}{*}{ Ecology } & Current and proposed protected areas & $1 \mathrm{~km}$ \\
\hline & Agriculture areas & $1 \mathrm{~km}$ \\
\hline & Birds communities & $300 \mathrm{~m}$ \\
\hline & Intensive animal farms & $1 \mathrm{~km}$ \\
\hline \multirow{3}{*}{$\begin{array}{l}\text { Major lines for } \\
\text { infrastructure }\end{array}$} & Current and proposed roads & $500 \mathrm{~m}$ \\
\hline & Oil and gas pipelines & $300 \mathrm{~m}$ \\
\hline & Power lines & $500 \mathrm{~m}$ \\
\hline
\end{tabular}

unsuitable land). Each group layers were merged to create a constraint layer for each group, and then the six constraint group layers were combined using the overlay function to create the final constraint map.

\subsubsection{Weighting the Acceptable Areas}

In practice, it is inappropriate to give equal importance to all criteria. Therefore, factor layers (Table 4) were applied at this stage to determine optimum sites for landfilling by classifying the remaining acceptable areas that were established in the second stage into classes of low and high suitability areas. All layers were weighted between 1 for highly suitable areas and increased to 9 for low suitable areas according to their level of significance. Six layers were involved in creating the factor maps, which include the soil characteristics, depth to groundwater, proximity to main roads network, urban, agriculture, and protected areas. These factors were selected as factor criteria due to their high sensitivity of selecting a landfill site close to these areas. The soil characteristics layer was weighted based on the soil penetration. However, each layer of urban areas, agriculture areas, protected areas, and main roads network have been given multi-buffer distance 
Table 4. Factor criteria.

\begin{tabular}{cc}
\hline Component & Description \\
\hline Soil & Suitable soil irrigated agriculture \\
Urban & Proximity to current urban areas \\
Road networks & Proximity to main roads \\
Hydrology & Depth to groundwater \\
Agriculture areas & Proximity to agriculture \\
Protected areas & Proximity to protected areas \\
\hline
\end{tabular}

from $500 \mathrm{~m}$ (considered as a low suitability area) to $5000 \mathrm{~m}$ (considered as a high suitability area). Groundwater factor was weighted based on how deep the groundwater was from the surface, where the high depth areas were given low values as a high suitable area, while the low depth areas were given high values as low suitable areas. Factor layers were also converted into raster format, reclassified into different classes, and overlaid together using the weighted overlay function in the spatial analysis tools.

\subsubsection{Final Suitability Map}

This approach consisted of the identification of locations that may present favorable conditions to waste disposal. The various layers prepared for environmental aspects were intersected to screen out unsuitable lands. The final constraint layer and the final factor layer were merged together using raster calculator to produce the final suitability map. A custom scale of 1 to 4 was chosen for this overlay since only four classes are appropriate for the final suitability maps. These four classes' areas comprise restricted, low suitability, moderate suitability, and high suitability. The high suitability locations were taken into consideration in the final stage.

\subsubsection{Selecting the Optimum Locations}

After the identification of suitable sites, the last stage is to evaluate these sites to locate the optimum locations by considering the socioeconomic aspects, namely waste transportation distance, proximity to roads network, and lifespan.

Waste transportation distance: It is estimated that a distance of more than $50 \mathrm{~km}$ from the waste generation center will take more than 40 minutes of driving. For this purpose, all areas located outside this range were eliminated.

Proximally to roads network. Landfill location must also be close to roads network in order to facilitate transportation and consequently reduce relative costs. However, the areas that are intersecting with roads network with a distance of $3 \mathrm{~km}$ were extracted.

Landfill lifespan: It is one of the critical criteria that must be considered due to the limited areas in Kuwait. Potential landfill area and volume must have the capacity to serve for at least 15 years. Therefore, the required volumes for MSW landfill sites and population projection were calculated using the following equa- 
tion [25]:

$$
V I=d\left(\frac{R}{w}\right) \times \text { Population }
$$

In which $V I$ is the required volume for the landfill per year, $R$ is the specific solid waste projection rate $(=1.4 \mathrm{~kg} / \mathrm{capita} / \mathrm{Day}), W$ is volumetric weight of solid waste after compacted ( $800 \mathrm{~kg} /$ cubic meter), and $D$ is number of day in one year (365 day/year).

\section{Results}

\subsection{Criteria Evaluation}

The results showed that Kuwait regulations covered the lowest number of the World Bank guidelines compared with Australia and USA. The Australian guidelines covered about $70 \%$ of the World Bank guidelines, USA covered about $50 \%$; however, Kuwait was the lowest, with $35 \%$. Various gaps have been identified between Kuwait and other countries. However, these gaps may not be a weakness in the regulations of the countries due to regional, climatic, and topographic differences. Therefore, these gaps were reviewed in order to select the ones that are applicable to desert environments such as Kuwait, and eliminate the ones that are not applicable. We found that most of these criteria are applicable and were considered in our analysis. Eighteen criteria were modified and added to the Kuwait regulations. We then generated a new list of criteria for the selection of municipal solid waste landfill sites in Kuwait, which was applied in this study to select suitable locations for landfilling in Kuwait. We also selected the needed information in order to assess each creation in the list. The new list of guidelines and needed data are summarized in the form of a table (Table 5). The results showed that the major weaknesses were concentrated in four components including lifespan, land use, site access and transportation, and socioeconomic factors.

\subsection{Optimum Locations for Landfill Sites}

The final factor layer (Figure 2(a)) and the final constraint layer (Figure 2(b)) were merged using raster calculator to produce the final suitability layer (Figure $2(c)$ ). The final suitable locations were classified into four classes including high suitability, moderate suitability, low suitability, and restricted based on the number of criteria covered by each class. The results showed that only $24.3 \mathrm{~km}^{2}$ of the entire country are highly suitable for landfilling. However, $1548 \mathrm{~km}^{2}$ are considered moderate suitability, $347 \mathrm{~km}^{2}$ are considered low suitable, and 14,367 $\mathrm{km}^{2}$ are restricted areas for landfilling. This illustrates that only few areas are highly suitable for landfill sites where all the selected criteria were met.

The suitability areas were then evaluated using socioeconomic criteria including waste transportation distance, proximity to roads network, and lifespan, to determine the optimum locations for landfilling. The lifespan was estimated for the highly suitable locations. As a result, the landfill volume depends on the 
Table 5. List of guidelines for the selection of suitable locations for landfilling in Kuwait.

\begin{tabular}{|c|c|c|c|c|}
\hline Component & Criteria & KEPA & Modified & Required maps \\
\hline \multirow{3}{*}{ Lifespan } & Depth of landfill from 10 to $25 \mathrm{~m}$ & & $\sqrt{ }$ & $\begin{array}{l}\text { Depth of groundwater }+ \\
\text { geological }\end{array}$ \\
\hline & $\begin{array}{l}\text { Land space and volume with a capacity to fill for at least } 20 \\
\text { years }\end{array}$ & & $\sqrt{ }$ & - \\
\hline & Solid waste density of $800-1000 \mathrm{~kg} /$ cubic meter & & $\sqrt{ }$ & - \\
\hline \multirow{7}{*}{$\begin{array}{l}\text { Topography and } \\
\text { climate }\end{array}$} & Away from areas of high wind & & $\sqrt{ }$ & Climate \\
\hline & Away from wetland areas should be at least $500 \mathrm{~m}$ & & & Sabkah + wetlands \\
\hline & Slopes topography about $2 \%$ & $\sqrt{ }$ & & Digital elevation model \\
\hline & No wades within 300 meters of landfill site & & $\sqrt{ }$ & Wades \\
\hline & Away from the underground recourse area & $\sqrt{ }$ & & Oil fields + oil wells \\
\hline & Away from rainfalls areas should be at least $500 \mathrm{~m}$ & $\sqrt{ }$ & & Depression: watershed \\
\hline & Away from moving sand areas should be at least $500 \mathrm{~m}$ & & $\sqrt{ }$ & Moving sand areas \\
\hline \multirow{3}{*}{ Soil } & $\begin{array}{l}\text { Availability of soil cover (for this purpose clay is the } \\
\text { best type of soil cover) }\end{array}$ & $\sqrt{ }$ & & Soil profile \\
\hline & $\begin{array}{l}\text { Soil should be impermeable in the landfill area (soil } \\
\text { permeability should be less than } 10^{-7} \mathrm{~cm} / \mathrm{s} \text { in order to } \\
\text { be used as landfill liner) }\end{array}$ & $\sqrt{ }$ & & Soil profile \\
\hline & Special consideration for suitability soil for revegetation & & $\sqrt{ }$ & Soil suitability \\
\hline \multirow{7}{*}{$\begin{array}{l}\text { Geology and } \\
\text { hydrology }\end{array}$} & No stream within 300 meters of landfill site & & $\sqrt{ }$ & Digital elevation model \\
\hline & $\begin{array}{l}\text { No fault lines within } 500 \text { meters or significantly fractured } \\
\text { geologic structure }\end{array}$ & $\sqrt{ }$ & & Geological structure \\
\hline & $\begin{array}{l}\text { Water catchment should be more than } 500 \text { meters } \\
\text { of landfill site }\end{array}$ & $\sqrt{ }$ & & Basin \\
\hline & Depth of the groundwater at least 10 meters & $\sqrt{ }$ & & Depth of groundwater \\
\hline & Away from seismic impact zones at least $100 \mathrm{~m}$ & & $\sqrt{ }$ & Potential seismic zones \\
\hline & $\begin{array}{l}\text { Away from the groundwater wells, filed and recharge areas } \\
(2 \mathrm{~km})\end{array}$ & $\sqrt{ }$ & & $\begin{array}{l}\text { Groundwater water filed + } \\
\text { wells + aquifers }\end{array}$ \\
\hline & Special consideration for aquifers $(2 \mathrm{~km})$ & $\sqrt{ }$ & & Groundwater aquifers \\
\hline \multirow{6}{*}{ Land use } & $\begin{array}{l}\text { Major lines of electrical transmission or other infrastructures } \\
\text { should be at least } 500 \mathrm{~m}\end{array}$ & & $\sqrt{ }$ & $\begin{array}{l}\text { Power lines + oil and gas } \\
\text { pipelines + oil trenches }\end{array}$ \\
\hline & Residential developments should be at least $2 \mathrm{~km}$ from landfill & $\sqrt{ }$ & & Land use \\
\hline & Airport area should be at least $1.5 \mathrm{~km}$ from landfill & & $\sqrt{ }$ & Land use \\
\hline & $\begin{array}{l}\text { Avoid sitting within } 1.5 \mathrm{~km} \text { from archeological and historical } \\
\text { areas }\end{array}$ & & $\sqrt{ }$ & Land use \\
\hline & $\begin{array}{l}\text { No sitting within } 2 \mathrm{~km} \text { from socio-politically sensitive areas } \\
\text { (agriculture areas, military areas, national parks, } \\
\text { entertainment areas and intensive animal's farms) }\end{array}$ & & $\sqrt{ }$ & Land use \\
\hline & $\begin{array}{l}\text { Endangered species breeding and significant protected areas as } \\
\text { well as areas that might lose habitat or have biodiversity } \\
\text { impacts should be at lest } 500 \text { meters from landfill }\end{array}$ & & $\sqrt{ }$ & $\begin{array}{l}\text { Bird nests }+ \text { protected area }+ \\
\text { vegetation areas }+ \text { land } \\
\text { suitability for revegetation }\end{array}$ \\
\hline \multirow{2}{*}{$\begin{array}{l}\text { Site access and } \\
\text { transport }\end{array}$} & Close to the road network & & $\sqrt{ }$ & Road network \\
\hline & $\begin{array}{l}\text { Transfer station, if needed, should be } 2 \text { hours of travel time } \\
\text { from landfill site }\end{array}$ & & $\sqrt{ }$ & Road network \\
\hline \multirow{2}{*}{ Economic factors } & Waste travel time of 30 minuets & & $\sqrt{ }$ & Road network \\
\hline & Availability of cover materials & $\sqrt{ }$ & & Soil characteristics \\
\hline
\end{tabular}




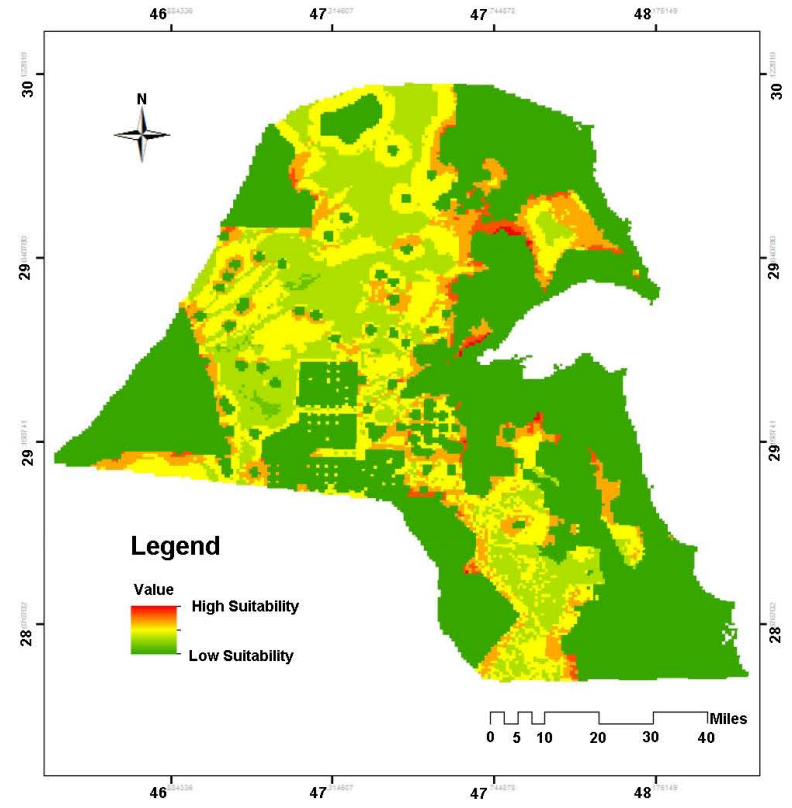

(a)

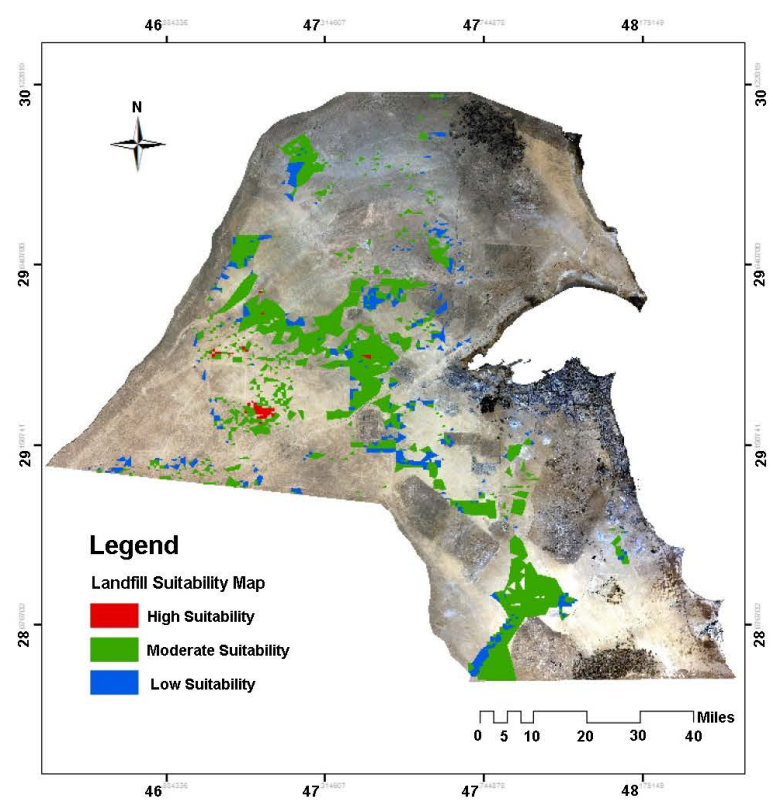

(c)

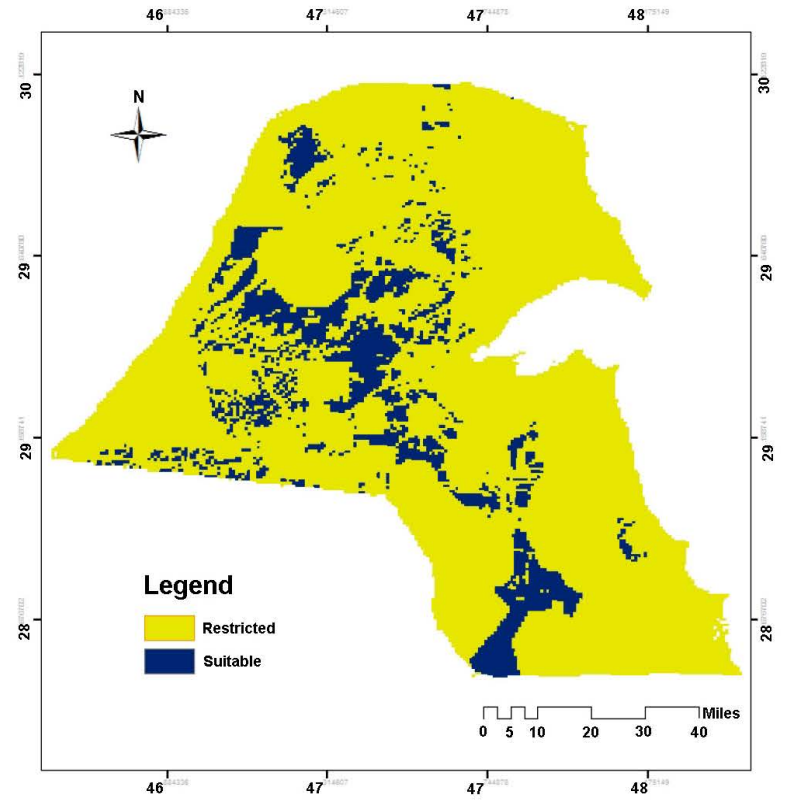

(b)

Figure 2. Suitable locations for Landfill sites in Kuwait: (a) Final factor layer, (b) Final constraint layer, and (c) Final suitability layer.

operation year. Moreover, starting early requires less volume instead of starting late due to the increase in waste generation and population every year. For such reasons, assumptions for the year 2018 were calculated. So, if the operation year starts at 2018, then the required volume for the landfill site will be $44,000,000 \mathrm{~m}^{3}$. Based on the required volume for landfill, it is assumed that the depth of the landfill is $10 \mathrm{~m}$ based on the average depth of the current landfill sites. Therefore, a total area of 4.5 square kilometers or greater is required to serve the waste 
generation at least 15 years (in case of starting the operation in 2015). Therefore, areas less than 4.5 square kilometers were eliminated. The results showed that only one location was greater than $4.5 \mathrm{~km}^{2}$; however, the remaining areas were less than $1 \mathrm{~km}^{2}$ to end up with only one optimum location with a total area of 12 $\mathrm{km}^{2}$ (Figure 3(a)) which can serve for at least 15 years (Table 6).

Since only one location was considered as an optimum location for landfilling, we relaxed the criteria to provide other alternative areas to support decision makers in Kuwait with alternative solutions. Alternative areas were extracted from the moderate suitability areas in the final suitability layer, which were also considered suitable areas. The same economic aspects criteria (including the waste transportation, distance to roads and landfill lifespan) were also applied to these areas. As a result, several alternative areas were located as suitable areas for landfill sites in Kuwait with a total area of $1328 \mathrm{~km}^{2}$ (Figure 3(b)). However, these locations could be considered suitable areas, but not optimum areas since they did not meet all the selected criteria. Therefore, they will require special implementation process to prevent any environmental disturbance.

\section{Discussion and Conclusions}

Our results show that developing a list of suitable criteria is a critical stage in the selection of suitable locations for landfilling. It is also necessary to integrate both environmental and socioeconomic aspects as the results show that the socioeconomic aspects including waste transportation distance, proximity to roads network, and lifespan play an important role in evaluating the suitable locations for landfilling.

We also find that the use of GIS model in the selection of suitable landfill sites incorporating the evaluation of multiple criteria has many advantages. Firstly, GIS is a powerful tool that enables organized and systematic analysis of spatial data. For instance, large amounts of data including thirty layers covering several different criteria are integrated and analyzed together, which is difficult to process without using the GIS spatial analysis. Secondly, the results of the analysis can also be presented in the form of functional output maps. Finally, the model and its operational procedures can be visually simplified and represented as a schematic diagram (flow chart). Therefore, GIS technology proves to be an effective tool that can be used in the landfill site selection. This system has the capability to handle a huge amount of spatial data and evaluate changes in scenarios as well as to save huge amounts of time.

The results of this work also show that only one location is conceded as an optimum site for landfilling. This indicates that there is an urgent need to implement the integrated waste management system [26] [27] by considering other options such as reuse and recycling. Alternative locations are also identified as another solution for landfill locations due to the limited optimum locations, and to provide decision makers with other alternatives. However, these alternative areas will most likely have environmental risks. Therefore, selecting landfill sites in these areas requires special designs that include liners, pipe network for 


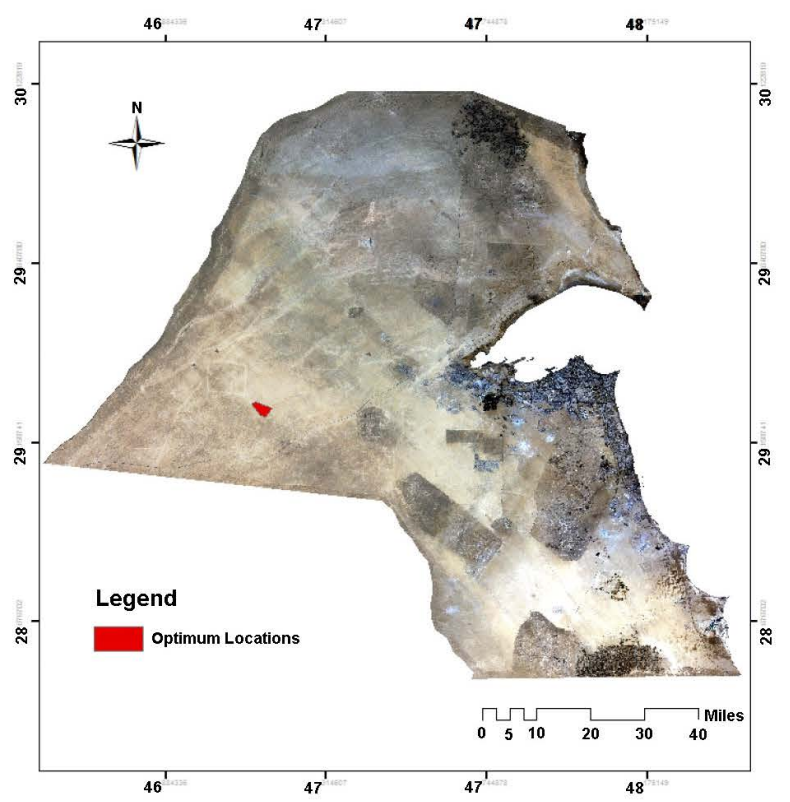

(a)

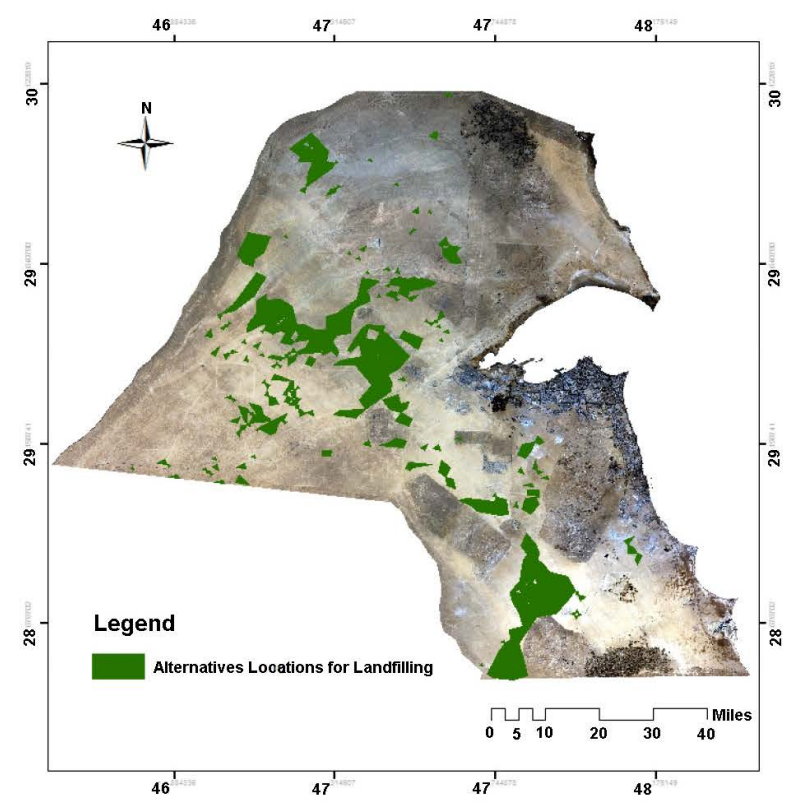

(b)

Figure 3. (a) Optimum Locations for landfilling after conducting the socioeconomic criteria, and (b) alternative locations for landfilling after relaxing the selected criteria to support decision makers.

Table 6. Total area for future potential landfill locations in Kuwait.

\begin{tabular}{cccc}
\hline & Suitable locations & $\begin{array}{c}\text { Optimum locations } \\
\text { (after conducting the social-economic factors) }\end{array}$ & Alternative locations \\
\hline Total area $\left(\mathrm{km}^{2}\right)$ & 24.3 & 12 & 1328 \\
\hline
\end{tabular}

gas and lechate collection, as well as groundwater monitoring. In addition, wind direction is another issue that must be considered in selecting landfill sites in the north and medial central areas of Kuwait, since the predominant wind direction in Kuwait is north-west [28], which may move the pollutant gases to urban areas. Furthermore, the moderate suitability sites located in southern areas are close to Al Wafra agriculture areas, which may also be affected if landfills are selected in close proximity.

It is also necessary to take into consideration the future increase in the volume of household waste due to the rapid population growth and the changes in life style. According to Kuwait-EPA [23], there is a relatively large increase in household waste generation, estimated at about $1.4 \mathrm{~kg}$ per person per day, generating about 1.5 million tons annually. More than $90 \%$ of the municipal solid wastes in Kuwait are disposed in landfill sites. Most of the current landfill sites are selected randomly and are close to urban areas. Currently, most of the existing landfills are under the rehabilitation program in order to reduce their potential negative impacts on the environment and human health [22] [23]. In view of the anticipated increase in population growth and the volumes of municipal solid wastes and limited waste management system in the country, landfilling will continue to be the main alternative in managing the produced volumes of wastes. Therefore, it is of a paramount importance to identify and locate the best 
suitable sites for MSW landfills to minimize their negative impacts on human health and the environment, as well as to develop a long-term strategic program (for the next ten to fifteen years) to conduct alternative environmental friendly options instead of landfilling.

This work presents an integrated methodology for selecting MSW sites by conducting and integrating environmental and socioeconomic criteria using GIS. We also believe that the developed methods in this work can be applicable to the selection of landfill sites at any location. However, in the next stage, we believe that it is important to conduct ground trothing field visit to evaluate these locations in the field, especially the alternative locations as several locations are identified and ranked from the highest to the lowest suitability. It is also important to update the criteria for landfill site selection in Kuwait as several gaps are identified. Therefore, we recommend using the selected criteria in this project to update the Kuwait EPA criteria.

\section{Conflicts of Interest}

The authors declare no conflicts of interest regarding the publication of this paper.

\section{References}

[1] Motlagh, Z.K. and Sayadi, M.H. (2015) Siting MSW Landfills Using MCE Methodology in GIS Environment (Case Study: Birjand Plain, Iran). Waste Management, 46, 322-337. https://doi.org/10.1016/j.wasman.2015.08.013

[2] El Maguiri, A., Kissi, B., Idrissi, L. and Souabi, S. (2016) Landfill Site Selection Using GIS, Remote Sensing and Multicriteria Decision Analysis: Case of the City of Mohammedia, Morocco. Bulletin of Engineering Geology and the Environment, 75, 1301-1309.

[3] Quadros, R., dos Santos, G.V., Tavares, A.N. and Bajay, S. (2015) Brazilian Research in Municipal Solid Waste Biogas: How Large Is It and How Far Has It Gone? Jour nal of Solid Waste Technology \& Management, 41, 95-105.

[4] Eiselt, H.A. and Marianov, V. (2015) Location Modeling for Municipal Solid Waste Facilities. Computers \& Operations Research, 62, 305-315. https://doi.org/10.1016/j.cor.2014.05.003

[5] Favery, R.L.T., et al. (2016) Study of Influential Factors on the Compaction of Municipal Solid Waste in Lysimeters. Journal of Solid Waste Technology \& Management, 42, 548-558.

[6] Leme, M.M.V., et al. (2014) Techno-Economic Analysis and Environmental Impact Assessment of Energy Recovery from Municipal Solid Waste (MSW) in Brazil. Resources, Conservation and Recycling, 87, 8-20. https://doi.org/10.1016/j.resconrec.2014.03.003

[7] Grisey, E. and Aleya, L. (2016) Assessing the Impact of Leachate Plumes on Groundwater Quality in the Etueffont Landfill (Belfort, France). Environmental Earth Sciences, 75, 1-18. https://doi.org/10.1007/s12665-016-5725-Z

[8] Atta, M., Yaacob, W.Z.W. and Jaafar, O.B. (2015) The Potential Impact of Leachate-Contaminated Groundwater of an Ex-Landfill Site at Taman Beringin Kuala Lumpur, Malaysia. Environmental Earth Sciences, 73, 3913-3923. https://doi.org/10.1007/s12665-014-3675-x 
[9] Zania, V., Psarropoulos, P.N., Karabatsos, Y. and Tsompanakis, Y. (2008) Inertial Distress of Waste landfills. Computers \& Structures, 86, 642-651. https://doi.org/10.1016/j.compstruc.2007.07.011

[10] Younes, M.K., et al. (2015) Integrating Approach to Size and Site at a Sanitary Landfill in Selangor State, Malaysia. Environmental Engineering Research, 20, 268-276. https://doi.org/10.4491/eer.2015.0054

[11] do Carmo Nascimento, I.O., et al. (2016) Post-Treatment of Sanitary Landfill Leachate by Coagulation-Flocculation Using Chitosan as Primary Coagulant. Water Science and Technology, 74, 246-255. https://doi.org/10.2166/wst.2016.203

[12] Fernandes, A., Santos, D., Pacheco, M.J., Ciríaco, L. and Lopes, A. (2016) Electrochemical Oxidation of Humic Acid and Sanitary Landfill Leachate: Influence of Anode Material, Chloride Concentration and Current Density. Science of the Total Environment, 541, 282-291. https://doi.org/10.1016/j.scitotenv.2015.09.052

[13] Arendse, L. and Godfrey, L. (2002) Waste Management Indicators for National State of Environment Reporting. Environmental Report, Centre for Scientific and Industrial Research (CSIR), South Africa, Pretoria.

[14] Armstrong, M. and Rowe, R. (1999) Effect of Landfill Operations on the Quality of Municipal Solid Waste Leachate. Proceedings of 3rd International Landfill Symposium, Cagliari, 1999, 81-88.

[15] Chang, N.-B., Parvathinathan, G. and Breeden, J.B. (2008) Combining GIS with Fuzzy Multicriteria Decision-Making for Landfill Siting in a Fast-Growing Urban Region. Journal of Environmental Management, 87, 139-153. https://doi.org/10.1016/j.jenvman.2007.01.011

[16] Nas, B., et al. (2010) Selection of MSW Landfill Site for Konya, Turkey Using GIS and Multi-Criteria Evaluation. Environmental Monitoring and Assessment, 160, 491-500. https://doi.org/10.1007/s10661-008-0713-8

[17] Siddiqui, M.Z., Everett, J.W. and Vieux, B.E. (1996) Landfill Siting Using Geographic Information Systems: A Demonstration. Journal of Environmental Engineering, 122, 515-523. https://doi.org/10.1061/(ASCE)0733-9372(1996)122:6(515)

[18] Xi, B., et al. (2010) An Integrated Optimization Approach and Multi-Criteria Decision Analysis for Supporting the Waste-Management System of the City of Beijing, China. Engineering Applications of Artificial Intelligence, 23, 620-631. https://doi.org/10.1016/j.engappai.2010.01.002

[19] Sadek, S., El-Fadel, M. and Freiha, F. (2006) Compliance Factors within a GIS-Based Framework for Landfill Siting. International Journal of Environmental Studies, 63 , 71-86. https://doi.org/10.1080/00207230600562213

[20] Vatalis, K. and Manoliadis, O. (2002) A Two-Level Multicriteria DSS for Landfill Site Selection Using GIS: Case Study in Western Macedonia, Greece. Journal of Geographic Information and Decision Analysis, 6, 49-56.

[21] Sekulović, D.J. and Jakovljević, G.L. (2016) Landfill Site Selection Using GIS Technology and the Analytic Hierarchy Process. Vojnotehnički glasnik, 64, 769-783. https://doi.org/10.5937/vojtehg64-9578

[22] Kuwait-EPA (2001) Decision No. 210/2001, Kuwait Al Youm, Appendix of Issue No. 533-Year 47. Kuwait Environment Public Authority.

[23] Kuwait-EPA (2003) The Rehabilitation Strategy of the Closed Municipal Waste Landfill Sites in Kuwait. Kuwait Environmental Public Authority.

[24] Kuwait-Municipality (2008) Municipal Solid Waste Quantities. Municipality of Kuwait: Landfill Site Management Department.

[25] Jaramillo, J. (2003) Guidelines for the Design, Construction and Operation of Ma- 
nual Sanitary Landfills. Pan American Center for Sanitary Engineering and Environmental Science.

[26] Heimlich, J.E., Hughes, K.L. and Christy, A.D. (1992) Integrated Solid Waste Management. Publication Louisiana Cooperative Extension Service.

[27] Şener, B., Süzen, M.L. and Doyuran, V. (2006) Landfill Site Selection by Using Geographic Information Systems. Environmental Geology, 49, 376-388. https://doi.org/10.1007/s00254-005-0075-2

[28] Neelamani, S., et al. (2007) Extreme Wind Speed from Different Directions in Kuwait. Wind Engineering, 31, 139-148. https://doi.org/10.1260/030952407781998846 